Issue 1 (September, 2017)

\title{
FAKTOR-FAKTOR YANG MEMPENGARUHI INTENSI BERWIRAUSAHA PADA MAHASISWA PROGRAM STUDI MANAJEMEN STIEM BONGAYA
}

\author{
1) Nuraeni Amir, ${ }^{2)}$ Herman Sjahruddin, ${ }^{3)}$ Nurlaely Razak \\ 1) Mahasiswa Program Studi Manajemen pada Sekolah Tinggi Ilmu Ekonomi \\ Bongaya Makassar \\ 2,3) Dosen Program Studi Manajemen pada Sekolah Tinggi Ilmu Ekonomi \\ Bongaya Makassar
}

\begin{abstract}
ABSTRAK
Peneltian ini bertujuan untuk menguji dan menganalisis faktor - faktor yang mempengaruhi intensi berwirausaha mahasiswa. Populasi yang digunakan pada studi ini adalah mahasiswa program studi manajemen Tahun angkatan 2013 - 2015 yang sifatnya un identified. Penarikan sampel dilakukan dengan menggunakan teknik Snowball Samping sehingga diperoleh 45 mahasiswa sebagai responden. Hasil pengujian dengan menggunakan analisis diskriminan memberikan bukti bahwa mahasiswa memiliki kebebasan dalam bekerja, toleransi risiko, dan keberhasilan diri yang tinggi sehingga memberikan kontribusi nyata terhadap tingginya keinginan mahasiswa untuk berwirausaha. Faktor terpenting dalam memunculkan intensi mahasiswa dalam berwirausaha ditunjukkan dengan tingginya keinginan mahasiswa untuk memiliki kebebasan dalam bekerja.
\end{abstract}

Kata Kunci: Kebebasan dalam bekerja, toleransi resiko, keberhasilan diri, intensi berwirausaha

\begin{abstract}
This study intens to to determine what factors influencing the students' entrepreneurial interest of Bongaya Institute of Economics of Makassar (STIEM Bongaya Makassar). The population of the study was unidentified. However, the population clustering used the students on academic years of 2013 to 2015. The sample was taken by applying snowball sampling technique, so that the sample obtained was consisted of 45 respondents. Based on the result of the study, it proved that the factors of working independently, risk tolerance, and self-efficacy had the positive and significant influence on the students' entrepreneurial interest of Bongaya Institute of Economics of Makassar. From the three of the factors, the dominant factor was working independently
\end{abstract}

Key words: $\quad$ working independently, risk tolerance, self-efficacy, entrepreneurial intention

Latar Belakang

Salah satu tantangan dalam pembangunan suatu negara adalah menangani masalah pengangguran. Data dari Badan Perencanaan Nasional (Bappenas) menunjukkan bahwa angka pengangguran di Indonesia masih sangat tinggi. Pada tahun 2013 tercatat bahwa dari 103.97 juta masyarakat Indonesia yang masuk angkatan kerja, sebanyak 7,02 juta orang atau sekitar 5,5 persen adalah 


\section{JURNAL ORGANISASI DAN MANAJEMEN}

Issue 1 (September, 2017)

pengangguran. Tingginya tingkat pengangguran tersebut didominasi oleh lulusan Sekolah Menengah Kejuruan dan Universitas dengan kisaran angka di atas 7 juta orang (Sumarsono, 2015)

Tingkat Pengangguran Sarjana yang mengalami kenaikan masing-masing sebesar 5,34 persen dan 6,22 persen di tahun 2016. Padahal mereka inilah yang seharusnya mampu diharapkan menjadi generasi penerus untuk bisa membawa kemajuan bagi bangsa ini (BPS, 2016). Menurut David McCelland suatu negara akan maju jika mempunyai paling sedikit 2 persen dari total jumlah penduduk adalah wirausaha (Sumarsono, 2015).

Idealnya wirausahawan di Indonesia saat ini sedikitnya 4.400 .000 atau $2 \%$ dari total jumlah penduduk, namun saat ini baru ada 400.000 pengusaha di Indonesia. Ironisnya, peningkatan jumlah pengangguran justru semakin didominasi oleh pengangguran yang terdidik. Hal ini mengindikasikan bahwa lulusan Perguruan Tinggi adalah lebih sebagai pencari kerja (job seeker) daripada pencipta lapangan pekerjaan (job creator) (Azwar, 2009).

Fakta empiris memberikan bukti bahwa tingkat pendidikan universitas justru mempunyai tingkat kesuksesan berwirausaha yang lebih rendah dibanding wirausaha dengan tingkat pendidikan sekolah menengah (Indarti dan Langerberg 2006; dalam Sumarsono 2015). Hasil penelitian tersebut menunjukan bahwa ada kemungkinan orientasi pendidikan atau kurikulum pendidikan ekonomi dan bisnis di Indonesia banyak yang tidak diarahkan untuk membentuk wirausahawan. Perguruan tinggi seharusnya tidak lagi mengutamakan bagaimana mahasiswa untuk cepat lulus dan mendapat pekerjaan. Tetapi Perguruan tinggi harusnya lebih fokus pada bagaimana lulusan mampu menciptakan pekerjaan. Untuk itu maka diperlukan upaya peningkatan intensi berwirausaha di kalangan mahasiswa. Intensi atau niat kesungguhan untuk berwirausaha harus tertanam dalam benak mahasiswa.

Intensi (minat) berwirausaha telah terbukti menjadi faktor penting/utama bagi perilaku kewirausahaan. Intensi berwirausaha juga dapat dijadikan sebagai pendekatan dasar yang masuk akal untuk memahami siapa-siapa yang akan menjadi wirausahawan. Seseorang dengan intensi untuk memulai usaha akan memiliki kesiapan dan kemajuan yang lebih baik dalam usaha yang dijalankan dibandingkan seseorang tanpa intensi untuk memulai usaha (Indarti dan Rostiani, 2008; dalam Sumarsono, 2015). Beberapa faktor-faktor yang memotivasi seseorang untuk menjadi entrepreneur yaitu keinginan merasakan pekerjaan bebas, keberhasilan diri yang dicapai, dan toleransi akan adanya risiko. Kebebasan dalam bekerja merupakan sebuah model kerja dimana seseorang melakukan pekerjaan sedikit tetapi memperoleh hasil yang besar (Adi Sutanto, 2000; dalam Mahesa dan Rahardja, 2012).

Keberhasilan diri yang dicapai merupakan pencapaian tujuan kerja yang diharapkan, meliputi kepuasan dalam bekerja dan kenyamanan kerja. Toleransi akan risiko, merupakan seberapa besar kemampuan dan kreativitas seseorang dalam menyelesaikan besar kecilnya suatu risiko yang diambil untuk mendapatkan penghasilan yang diharapkan. Semakin besar kemampuan diri seseorang, maka semakin besar pula keyakinanya terhadap kesanggupan mendapatkan hasil dari keputusanya serta keyakinanya untuk mencoba apa yang dilihat orang lain berisiko (Mahesa dan Rahardja, 2012).

Teori motivasi yang dikemukakan (Davis dan New Storm, 1996; dalam Tama, 2010) bahwa dorongan/motivasi individu untuk bekerja terdiri dari: 


\section{JURNAL ORGANISASI DAN MANAJEMEN}

Issue 1 (September, 2017)

1. Motivasi prestasi (achievement motivation), adalah dorongan dalam diri seseorang untuk mengatasi segala tantangan dan hambatan dalam mencapai tujuan. Entrepreneur yang berorientasi dan bekerja keras apabila mereka memandang bahwa mereka akan memperoleh kebanggaan pribadi atas upaya mereka.

2. Motivasi afiliasi (affiliation motivation), adalah dorongan untuk berhubungan dengan orang-orang atas dasar sosial. Orang-orang yang memiliki motivasi afiliasi bekerja lebih baik apabila mereka dipuji karena sikap dan kerja sama mereka yang menyenangkan.

3. Motivasi kompetensi (competence motivation), adalah dorongan untuk mencapai keunggulan kerja, meningkatkan keterampilan dalam memecahkan masalah, dan berusaha keras untuk inovatif.

4. Motivasi kekuasaan (power motivation), adalah dorongan untuk mempengaruhi orang-orang dan mengubah situasi. Orang-orang yang bermotivasi kekuasaan ingin menimbulkan dampak dan mau memikul risiko untuk melakukan hal itu.

Penjelasan di atas dapat ditarik kesimpulan bahwa motivasi adalah suatu dorongan dari dalam diri manusia maupun dorongan dari pihak luar untuk mencapai suatu tujuan yang diinginkan. Faktor yang menyebabkan tumbuhnya minat mahasiswa untuk berwirausaha, terdiri dari faktor pendapatan, perasaan senang, lingkungan keluarga dan pendidikan (Suhartini, 2011). Studi lainnya menemukan faktor yang berbeda, inovasi, kebutuhan untuk berprestasi dan pengambilan risiko berpengaruh signifikan terhadap niat kewirusahaan mahasiswa, sebaliknya latar belakang keluarga tidak berpengaruh signifikan terhadap niat kewirausahaan (Malo, 2010).

Terdapat beberapa motivasi yang mempengaruhi minat berwirausaha, misalnya keinginan untuk dihormati, melanjutkan tradisi keluarga, mendapatkan pendapatan lebih baik (Venesaar et al., 2006; dalam Uswaturrasul dan Sisilia, 2011). Variabel lingkungan keluarga, sikap mental mahasiswa dan persepsi mahasiswa berwirausaha mempunyai pengaruh positif terhadap minat berwirausaha mahasiswa (Gallyn, 2011; dalam Paulus Patria Adhitama, 2014). Selanjutnya hasil penelitian (Ariyani 2016) menunjukan bahwa variabel efikasi diri, norma subjektif, dan pendidikan berpengaruh signifikan terhadap intensi kewirausahaan. Sementara temuan penelitian (Adeline dan Srimulyani, 2014; dalam Wardana, 2016) menemukan bahwa faktor toleransi terhadap risiko berpengaruh positif dan signifikan terhadap minat berwirausaha seseorang.

Penelitian yang dilakukan Adeline (2011), Oktaliris (2012), serta Satiti dan Ekowati (2014) dalam (Wardana, 2016), menunjukkan bahwa keinginan merasakan kebebasan dalam bekerja berpengaruh positif dan signifikan terhadap minat berwirausaha, hal ini menjelaskan bahwa seseorang ingin merasakan kebebasan dalam bekerja atau dengan kata lain tidak dibawah pengawasan. Pemilihan faktor yang mempengaruhi intensi (minat) berwirausaha terhadap mahasiswa mengadopsi pengukuran yang digunakan Mahesa dan Rahardja, (2012) meliputi, faktor kebebasan dalam bekerja, toleransi risiko dan keberhasilan diri.

Berdasarkan hasil pengamatan terhadap mahasiswa STIEM Bongaya dapat diidentifikasi bahwa terdapat beragam jenis wirausaha yang dilakukan mahasiswa, seperti usaha kuliner, kafe, usaha elektronik, salon kecantikan, dan fashion serta bisnis online marketing. Berdasarkan hasil wawancara terhadap beberapa mahasiswa, ditemukan bahwa terdapat beberapa faktor yang mempengaruhi 
keinginan mereka untuk berwirusaha, di antaranya bahwa mereka bebas untuk melaksanakan usaha apa saja tanpa ada perintah dari orang lain, dengan berwirausaha mereka memperoleh penghasilan untuk membayar uang kuliah mereka, membantu orangtua, belajar mandiri, mengikuti tradisi keluarga dan risiko berwirausaha relatif kecil.

\section{METODE PENELITIAN}

Berdasarkan jenisnya, penelitian ini termasuk dalam penelitian penjelasan (explanatory research) dalam penelitian ini peneliti menggunakan penelitian explanatory (penjelasan) bertujuan untuk menguji hubungan antara variabel atau bagaimana suatu variabel mempengaruhi variabel lainnya. Penelitian ini juga termasuk pendekatan penelitian kuantitatif, disebut kuantitatif karena banyak menggunakan angka, mulai dari pengumpulan data, penafsiran terhadap data serta dari penampilan dan hasilnya, demikian juga dengan pemahaman akan kesimpulan penelitian. (Arikunto, 2002 : 9, dalam Sinolla, 2011).

Populasi dalam penelitian ini adalah Mahasiswa Strata satu pada program studi Manajemen STIEM BONGAYA angkatan Tahun 2013 sampai dengan 2015 yang jumlahnya tidak dapat diketahui (unidentified) penarikan sampel dalam penelitian ini menggunakan metode snowball sampling yaitu teknik penentuan sampel yang mula-mula jumlahnya kecil, kemudian sampel ini disuruh memilih teman-temannya untuk dijadikan sampel begitu seterusnya, sehingga jumlah sampel semakin banyak. Ibarat bola salju yang menggelinding semakin lama semakin besar (Sugiyono, 2001: 61), oleh karena itu sampel diambil dalam penelitian ini sebanyak 45 responden. Metode pengumpulan data dalam penelitian ini menggunakan kuisioner, item-item peryataan yang diajukan dalam skala Likert. Penelitian ini menggunakan teknik analisis uji instrument, uji asumsi klasik, uji analisis statistic deskriptif dan uji analisis regresi diskriminan yang dilakukan dengan menggunakan program SPSS 21.

\section{ANALISA DAN PEMBAHASAN}

Ada beberapa profil responden pada penelitian ini menunjukkan bahwa 55.6 responden adalah pria dan $44.4 \%$ responden adalah perempuan. Rentang usia responden penelitian ini berkisar antara 18 tahun hingga 26 tahun, dimana mayoritas responden atau $73.3 \%$ berusia antara $21-23$ tahun, $20 \%$ berusia antara 18-20 tahun dan 6.7\% berusia antara 23-26 tahun. Berdasarkan masa studi atau angkatan tahun pada penelitian ini, mayoritas responden atau $51.1 \%$ angkatan tahun 2013, 28.9\% angkatan tahun 2015 dan 20.0\% angkatan tahun 2014. Sedangkan berdsarkan lama berwirausaha pada ini penelitian ini, mayoritas $51.1 \%$ responden melakukan wirausaha kurang dari satu sedangkan yang melakukan wirausaha diatas satu tahun adalah $48.9 \%$ responden. Peneltian terhadap indikator kebebasan dalam bekerja, mayoritas responden 45 responden (76.40\% atau 3.82) dari total responden dicirikan keras kepala atau memiliki rasa keinginan bebas dalam pekerjaannya. Penilaian terhadap indikator toleransi risiko dari 45 responden, mayoritas responden $(77.40 \%$ atau 3.87$)$ dari total responden selalu 


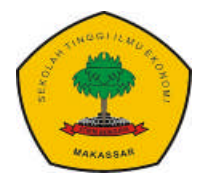

\section{JURNAL ORGANISASI DAN MANAJEMEN}

Issue 1 (September, 2017)

berfikir panjang dalam menghadapi risiko yang akan di ambil. Sedangkan penelitian terhadap indicator keberhasilan diri, mayoritas responden $(79.60 \%$ atau 3.89$)$ dari total responden dicirikan memiliki sikap optimis terhadap keberhasilan diri.

\section{A. Uji Instrumen Penelitian}

Uji validitas menunjukkan sejauh mana ketepatan, kesesuaian, atau kecocokan suatu alat untuk mengukur apa yang akan diukur. Suatu indikator dikatakan valid jika nilai person correlation $(\mathrm{r}=>0.30$ ) dan tingkat signifikansinya ( $\alpha$ $=<0.05$ ) (Murti dan Salamah, 2006:65, dalam Raditya, 2016). Uji reliabilitas data dilakukan dengan menghitung crobanch's alpha dari masing-masing instrumen dalam suatu konstruk. Instrumen dikatakan handal (reliabel) apabila memiliki crobanch's alpha = >0,60 (Arikunto, 1998:164, dalam Sahlan, dkk., 2015).

Tabel 1. Uji Instrument penelitian

\begin{tabular}{|c|c|c|c|}
\hline Variabel & Pearson Correlation & Sig. (2-tailed) & crobanch's alpha $>0,60$ \\
\hline \multirow{5}{*}{ Kebebasan Dalam Bekerja } & $.679^{* *}$ & .000 & \multirow{5}{*}{.800} \\
\hline & $.784^{* *}$ & .000 & \\
\hline & $.841^{* *}$ & .000 & \\
\hline & $.752^{* *}$ & .000 & \\
\hline & $.677^{* *}$ & .000 & \\
\hline \multirow{5}{*}{ Toleransi Risiko } & $.843^{* *}$ & .000 & \multirow{5}{*}{.869} \\
\hline & $.850^{* *}$ & .000 & \\
\hline & $.704^{* *}$ & .000 & \\
\hline & $.867^{* *}$ & .000 & \\
\hline & $.788^{* *}$ & .000 & \\
\hline \multirow{5}{*}{ Keberhasilan Diri } & $.761^{* *}$ & .000 & \multirow{5}{*}{.826} \\
\hline & $.760^{* *}$ & .000 & \\
\hline & $.863^{* *}$ & .000 & \\
\hline & $.741^{* *}$ & .000 & \\
\hline & $.736^{* *}$ & .000 & \\
\hline
\end{tabular}

Hasil uji validitas instrumen berada diatas angka kritik tabel dan memiliki nilai signifikansi di bawah 0,05 . Hal tersebut berarti bahwa seluruh butir pernyataan pada variabel kebebasan dalam bekerja, toleransi risiko dan keberhasilan diri mempunyai kriteria valid. Nilai cronbach's alpha atas variabel kebebasan dalam bekerja sebesar 0.800 , toleransi risiko sebesar 0.869 , dan keberhasilan diri sebesar 0.826 . Dengan demikian, dapat disimpulkan bahwa pernyataan dalam kuesioner ini reliabel karena mempunyai nilai cronbach's alpha lebih besar dari 0,60.

\section{B. Uji Normalitas}

Pengujian normalitas dilakukan terhadap masing-masing variabel secara individual maupun melalui multivariate dari nilai residual regresi. Pengujian dilakukan dengan menggunakan uji Kolmogorov Smirnov.

Tabel 2. Uji Normalitas Data

One-Sample Kolmogorov-Smirnov Test 


\begin{tabular}{|ll|r|}
\hline & & Unstandardized Predicted Value \\
\hline $\mathrm{N}$ & & 45 \\
Normal Parameters $\mathrm{a}, \mathrm{b}$ & Mean & 56.6222 \\
& Std. Deviation & 7.08163 \\
& Absolute & .110 \\
Most Extreme Differences & Positive & .074 \\
& Negative & -.110 \\
Kolmogorov-Smirnov Z & & .735 \\
Asymp. Sig. (2-tailed) & & .653 \\
\hline
\end{tabular}

a. Test distribution is Normal.

b. Calculated from data.

Berdasarkan Tabel diatas, mengacu pada nilai Asymp. Sig.(2-tailed), maka harus dibandingkan dengan tingkat alpha yaitu sebesar $5 \%$ atau 0.05 . kriteria yang digunakan yaitu $\mathrm{H}_{0}$ diterima apabila nilai Asymp. Sig.(2-tailed) 0,653>0,05 dari tingkat alpha yang ditetapkan yaitu sebesar 5\%, sehingga dapat disimpulkan bahwa data yang di analisis terdistribusi secara normal.

\section{Uji Ananlisis Variabel Diskriminan}

\section{a) Analisis Statistik Deskriptif}

Untuk memberikan deskripsi mengenai variabel-variabel penelitian (Keberhasilan diri, toleransi risiko, kebebasan dalam bekerja), digunakan dalam tabel distribusi frekuensi absolut yang menunjukkan angka maksimum, minimum, rata-rata, dan standar deviasi.

Tabel 2. Statistik Deskriptif

\begin{tabular}{|c|c|c|c|c|c|}
\hline & \multirow{2}{*}{ Grup } & \multirow{2}{*}{ Mean } & \multirow{2}{*}{ Std. Deviation } & \multicolumn{2}{|c|}{ Valid N (listwise) } \\
\hline & & & & Unweighted & Weighted \\
\hline \multirow{3}{*}{1} & Kebebasan Dalam Bekerja & 16.5217 & 2.81020 & 23 & 23.000 \\
\hline & Toleransi Risiko & 17.1304 & 3.67181 & 23 & 23.000 \\
\hline & Keberhasilan Diri & 17.3478 & 2.94817 & 23 & 23.000 \\
\hline \multirow{3}{*}{2} & Kebebasan Dalam Bekerja & 20.2727 & 2.18614 & 22 & 22.000 \\
\hline & Toleransi Risiko & 20.9545 & 2.71639 & 22 & 22.000 \\
\hline & Keberhasilan Diri & 21.2727 & 2.39408 & 22 & 22.000 \\
\hline \multirow{3}{*}{ Total } & Kebebasan Dalam Bekerja & 18.3556 & 3.13453 & 45 & 45.000 \\
\hline & Toleransi Risiko & 19.0000 & 3.74166 & 45 & 45.000 \\
\hline & Keberhasilan Diri & 19.2667 & 3.31936 & 45 & 45.000 \\
\hline
\end{tabular}

Tabel Group Statistics menunjukkan rata-rata dan standar deviasi dari setiap kelompok perkarakteristik. Tabel di atas menerangkan bahwa faktor-faktor yang mempengaruhi minat berwirausaha mahasiswa terdapat 45 responden, dimana sebanyak 23 responden masuk ke dalam grup 1 dan sebanyak 22 responden masuk ke dalam grup 2 . Pada variabel $\mathrm{X}_{1}$ nilai rata-rata $\mathrm{X}_{1}$ terhadap minat berwirausaha 
pada grup 1 (mahasiswa yang berwirausaha $<1$ tahun) sebesar $18.35 \%$, sedangkan grup 2 (mahasiswa yang berwirausaha $>1$ tahun) sebesar $20.27 \%$. Artinya ratarata $\mathrm{X}_{1}$ terhadap minat berwirausaha pada grup 1 lebih rendah dibandingkan dengan grup 2. Begitupun dengan variabel $X_{2}$ dan $X_{3}$ yang memiliki nilai rata-rata lebih rendah dibandingkan nilai rata-rata grup 2. Hal tersebut mengindikasikan bahwa pengaruh minat berwirausaha terhadap grup 2 paling positif dibandingkan grup 1.

\section{b) Analisis Regresi Diskriminan}

Analisis diskriminan, yaitu metode statistik untuk mengelompokkan atau mengklasifikasi sejumlah objek ke dalam beberapa kelompok pada variabel intensi berwirausaha (grup $1=$ berwirausaha $<1$ tahun dan grup $2=$ berwirausaha $>1$ tahun), sehingga setiap objek menjadi anggota dari satu kelompok

\section{1) Uji Kesamaan Matrix Ragam-Peragam}

Untuk menguji asumsi kesamaan matrix ragam peragam antar grup 1 yaitu mahasiswa yang berwirausaha $<1$ tahun dengan grup 2 yaitu mahasiswa yang berwirausaha $>1$ tahun, maka dapat ditunjukkan pada tabel berikut.

\section{Tabel 3. Log Determinants}

\begin{tabular}{|l|r|r|}
\hline Grup & Rank & Log Determinant \\
\hline 1 & 3 & 6.778 \\
2 & 3 & 4.896 \\
Pooled within-groups & 3 & 6.067 \\
\hline
\end{tabular}

The ranks and natural logarithms of determinants printd are those of the group covariance matrices.

\section{2) Hasil Uji Box's M}

Tabel 4. Box's M

\begin{tabular}{|ll|r|}
\hline Box's M & & 8.924 \\
& Approx. & 1.374 \\
F & df1 & \\
& df2 & 6 \\
& Sig. & 13319.259 \\
& & .221 \\
\hline
\end{tabular}

Tests null hypothesis of equal population covariance matrices.

Grup 1 dan grup 2 meliki matrix ragam-peragam yang sama dilihat nilai signifikan $0.226>0.05$ (alpha). Asumsi semua grup memiliki matrix ragam-peragam yang sama terpenuhi. Selain itu, kesimpulan dapat diambil dengan nilai log determinan dari tiap-tiap grup pada tabel log determinans. Nilai log determinan pada grup $1=6.778$ dan grup $2=4.896$. Hasil keduanya relatif sama, hal tersebut mengindikasikan ragam-peragam untuk tiap grup sama. Dengan melihat nilai signifikansi yang lebih kecil dari alpha 0.05, sehingga dapat dikatakan bahwa terdapat perbedaan rata-rata antara grup 1 dan 2 dengan asumsi perbedaan rata- 
Issue 1 (September, 2017)

rata antar grup terpenuhi. Salah satu asumsi yang harus ada dalam analisis diskriminan adalah homogenitas varians. Nilai homogenitas dapat dilihat dari nilai Statistic Box's M.

Hipotesis

$\mathrm{H}_{0}$ : Varians antara dua kelompok data identik / homogen

$\mathrm{H}_{\mathrm{a}}$ : Varians antara dua kelompok data tidak identik / heterogen

Tolak Hipotesis nol apabila nilai p-value statistic box's $M$ lebih kecil dari 0.05. Dari hasil $p$-value statistik box's $M$ diketahui bahwa nilai Box's $M$ sebesar 8.942 dengan signifikansi nilai $p$-value 0.0221, maka hipotesis nol diterima, hal tersebut berarti varians antara data kelompok satu dan kelompok dua adalah data yang sifatnya homogen.

\section{3) Uji Wilks' Lambda}

Tabel 5. Wilks' Lambda

\begin{tabular}{|l|r|r|r|r|}
\hline Test of Function(s) & $\begin{array}{c}\text { Wilks' } \\
\text { Lambda }\end{array}$ & Chi-square & Df & \multicolumn{1}{|c|}{ Sig. } \\
\hline 1 & .304 & 49.392 & 3 & .000 \\
\hline
\end{tabular}

Nilai Wilk's Lamda berkisar antara 0 hingga 1. Nilai Wilk's Lamda mendekati nol menunjukkan arti semakin signifikan karakteristik tersebut membedakan antara dua variasi kelompok. Sebaliknya, nilai Wilk's Lamda semakin mendekati angka 1, maka variasi data untuk karakteristik tersebut cenderung sama untuk dua kelompok tersebut.

Berdasarkan pengujian Wilks' Lambda, maka diperoleh nilai Wilks' Lambda sebesar $0,304<1$ maka dapat dinyatakan bahwa variasi data untuk variabel kebebasan dalam bekerja $\left(\mathrm{X}_{1}\right)$, toleransi risiko $\left(\mathrm{X}_{2}\right)$ dan keberhasilan diri $\left(\mathrm{X}_{3}\right)$ cenderung berbeda anatara group 1 (lamanya mahasiswa berwirausaha $<1$ Tahun) dengan group 2 (lamanya mahasiswa berwirausaha $>1$ Tahun). Hal serupa juga dapat dilihat pada nilai signifikansi hasil uji Wilk's Lamda

\section{4) Uji Struktur Matrix}

Tabel 6. Structure Matrix

\begin{tabular}{|l|cc|}
\hline & \multicolumn{2}{|c|}{ Function } \\
\cline { 2 - 3 } & \multicolumn{2}{|c|}{1} \\
\hline Kebebasan Dalam Bekerja & & .502 \\
Keberhasilan Diri & & .493 \\
Toleransi Risiko & & .399 \\
\hline
\end{tabular}

Pooled within-groups correlations between discriminating variabels and standardized canonical discriminant functions

Variabels ordered by absolute size of correlation within function.

Tabel struktur Matrix menunjukkan urutan karasteristik yang paling membedakan minat berwirausaha $(\mathrm{Y})$. Variabel kebebasan dalam bekerja $\left(\mathrm{X}_{1}\right)$ adalah yang paling membedakan karena memiliki nilai tertinggi sebesar 0.502 dibandingkan dengan nilai dimensi toleransi risiko $\left(\mathrm{X}_{2}\right)$ 0.399, dan nilai dimensi 
keberhasilan diri $\left(\mathrm{X}_{3}\right)$ sebesar 0.493 . Tabel di atas menunjukkan adanya korelasi antar variabel-variabel bebas dengan fungsi diskriminan yang terbentuk.

5) Uji Canonical Diskriminant dan Group Centreoids

Tabel 6. Canonical Discriminant Function Coefficients

\begin{tabular}{|l|rr|}
\hline \multirow{2}{*}{} & \multicolumn{2}{|c|}{ Function } \\
\cline { 2 - 3 } & \multicolumn{1}{|c|}{1} \\
\hline Kebebasan Dalam Bekerja & & .310 \\
Toleransi Risiko & & .172 \\
Keberhasilan Diri & .290 \\
(Constant) & & -14.540 \\
\hline
\end{tabular}

Unstandardized coefficients

6) Uji Functions at Group Centroids

Tabel 7. Functions at Group Centroids

\begin{tabular}{|c|c|}
\hline \multirow[t]{2}{*}{ Grup } & Function \\
\hline & 1 \\
\hline $\begin{array}{l}1 \\
2\end{array}$ & $\begin{array}{r}-1.446 \\
1.512\end{array}$ \\
\hline
\end{tabular}

Unstandardized canonical discriminant functions evaluated at group means

Tabel Canonical Discriminat Function Coefficients di atas menunjukkan fungsi diskriminan dengan persamaan sebagai berikut

$$
\text { Z-score }=-14.540 \text { (konstan) }+0.310 \mathrm{X} 1+0,172 \mathrm{X} 2+0,290 \mathrm{X} 3 .
$$

Fungsi ini berguna untuk menganalisis kasus atau responden yang diteliti akan termasuk ke dalam grup mana, yaitu grup 1 untuk mahasiswa yang berwirausaha $<1$ tahun, grup 2 untuk mahasiswa yang berwirausaha $>1$ tahun. Berdasarkan angka tabel di atas, terdapat dua grup yang berbeda yaitu grup 1 dengan centroid (rata-rata kelompok) negatif dan grup 2 dengan centroid (rata-rata kelompok) positif.

\section{7) Uji Hasil Klasifikasi}

Tabel 8. Classification Resultsa

\begin{tabular}{|c|c|c|c|c|c|}
\hline \multirow{2}{*}{\multicolumn{3}{|c|}{ Grup }} & \multicolumn{2}{|c|}{ Predicted Group Membership } & \multirow[t]{2}{*}{ Total } \\
\hline & & & 1 & 2 & \\
\hline \multirow{4}{*}{ Original } & \multirow{2}{*}{ Count } & 1 & 23 & 0 & 23 \\
\hline & & 2 & 0 & 22 & 22 \\
\hline & \multirow{2}{*}{$\%$} & 1 & 100.0 & .0 & 100.0 \\
\hline & & 2 & .0 & 100.0 & 100.0 \\
\hline
\end{tabular}

$100.0 \%$ of original grouped cases correctly classified.

Tabel di atas pada kolom Original baris grup 1 sebanyak 23 responden atau sebesar $100 \%$, sedangkan baris grup 2 sebanyak 22 responden atau sebesar $100 \%$. 
Issue 1 (September, 2017)

Dengan demikian dapat diketahui bahwa jumlah keseluruhan responden sebesar 45 responden dan terdistribusi secara normal.

8) Uji Rata-Rata Tingkat Kesesuaian Grup

Tabel 9. Tests of Equality of Group Means

\begin{tabular}{|l|r|r|r|r|r|}
\hline & Wilks' Lambda & F & df1 & \multicolumn{1}{c|}{ df2 } & \multicolumn{1}{c|}{ Sig. } \\
\hline Kebebasan Dalam & .634 & 24.819 & 1 & 43 & .000 \\
Bekerja & & & & & \\
Toleransi Risiko & .733 & 15.658 & 1 & 43 & .000 \\
Keberhasilan Diri & .643 & 23.905 & 1 & 43 & .000 \\
\hline
\end{tabular}

Nilai rata-rata kesesuaian antar grup berdasarkan tingkat signifikansinya menunjukkan bahwa ;

1) Variabel kebebasan dalam bekerja dengan nilai signifikansi ( $P$-value) sebesar $0.000<0.05$ hal tersebut menjelaskan bahwa semakin tinggi tingkat kebebasan mahasiswa dalam bekerja maka semakin tinggi minat mahasiswa untuk berwirausaha.

2) Variabel toleransi risiko dengan nilai signifikansi ( $P$-value) sebesar 0.000 $<0.05$ hal tersebut menjelaskan bahwa semakin tinggi tingkat toleransi risiko maka semakin tinggi minat mahasiswa untuk minat berwirausaha.

3) Variabel keberhasilan diri dengan nilai signifikansi ( $P$-value) sebesar $0.000<0.05$ hal tersebut menjelaskan bahwa semakin tinggi tingkat keberhasilan diri maka semakin tinggi minat mahasiswa untuk minat berwirausaha.

Pembuktian penerimaan hipotesa dalam penelitian ini menggunakan uji fisher (uji-f), yang dapat diuraikan sebagai berikut:

1) Jika $f_{\text {-hitung }}<f_{\text {-tabel, }}$ maka $\mathrm{H}_{0}$ diterima dan $\mathrm{H}_{\alpha}$ ditolak, bahwa terdapat pengaruh yang tidak signifikan antara variabel kebebasan dalam bekerja, toleransi risiko dan keberhasilan diri terhadap minat berwirausaha

2) Jika $f$-hitung $>f$-tabel, maka $\mathrm{H}_{0}$ ditolak dan $\mathrm{H}_{\alpha}$ diterima, bahwa terdapat pengaruh yang signifikan antara variabel kebebasan dalam bekerja, toleransi risiko dan keberhasilan diri terhadap minat berwirausaha

Hasil penelusuran nilai $f$-tabel dapat ditelusuri dengan menggunakan bantuan microsoft excel, untuk itu dapat ditunjukkan pada gambar berikut:

Gambar 1. Hasil Uji f-tabel

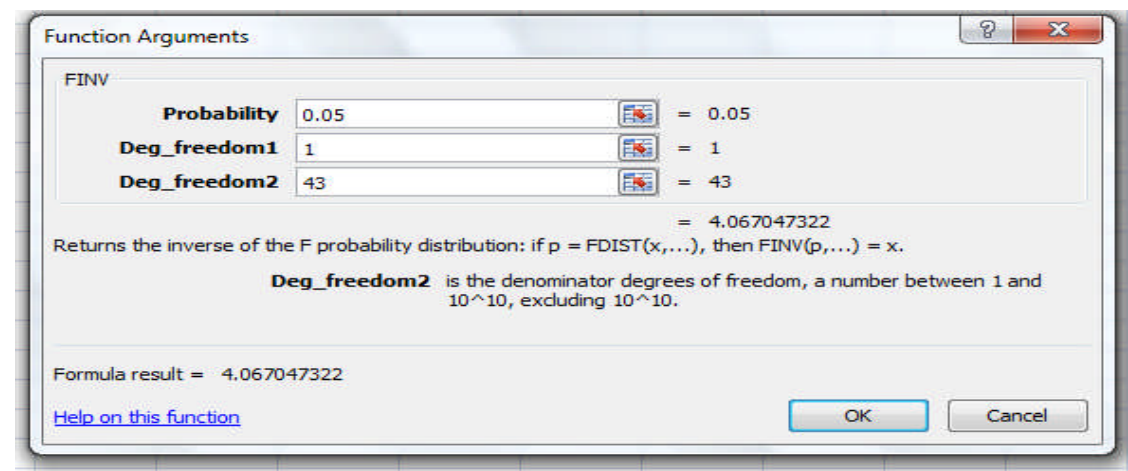

Gambar tersebut menunjukkan bahwa nilai degree of freedom untuk df $1=1$ dan pada df $2=43$ sehingga berdasarkan hasil tersebut dapat ditentukan nilai $f$ tabel sebesar 4.0670. Merujuk pada hasil uji rata-rata hasil kesesuain grup dan nilai 


\section{JURNAL ORGANISASI DAN MANAJEMEN}

Issue 1 (September, 2017)

f-tabel maka dapat dijelaskan faktor-faktor yang signifikan membedakan antara dua grup yaitu grup satu untuk mahasiswa yang berwirausaha kurang dari satu tahun dan grup dua untuk mahasiswa yang berwirausaha lebih dari satu tahun. Untuk uji-f digunakan sebagai uji hipotesis dan nilai $p$-value (signifikan) di mana jka $p$-value $>$ 0,05 , berarti tidak ada perbedaan antara group dan jika $p$-value $<0,05$, artinya terdapat perbedaan antara group. Berdasarkan pengujian yang telah dilakukan, maka :

1) Variabel karakteristik kebebasan dalam bekerja mempunyai nilai f-hitung pada variabel kebebasan dalam bekerja sebesar $24.819>f$-tabel sebesar 4.067. Kemudian nilai $p$-value sebesar $<0,05$, hal ini berarti bahwa group satu (mahasiswa yang berwirausaha $<1$ tahun) memiliki persepsi yang signifikan berbeda dengan group dua (mahasiswa yang berwirausaha $>1$ tahun) atas minat berwirausaha.

2) Variabel karakteristik toleransi risiko mempunyai nilai f-hitung pada variabel toleransi risiko sebesar $15.658>f$-tabel sebesar 4.067. Kemudian nilai $p$-value sebesar $<0,05$, hal ini berarti bahwa group satu (mahasiswa yang berwirausaha $<1$ tahun) memiliki persepsi yang signifikan berbeda dengan group dua (mahasiswa yang berwirausaha $>1$ Tahun) atas minat berwirausaha.

3) Variabel karakteristik keberhasilan diri mempunyai nilai f-hitung pada variabel keberhasilan diri sebesar $23.905>f$-tabel sebesar 4.067. Kemudian nilai $p$-value sebesar $<0,05$, hal ini berarti bahwa group satu (mahasiswa yang berwirausaha $<1$ Tahun) memiliki persepsi yang signifikan berbeda dengan dan group dua (mahasiswa yang berwirausaha $>1$ Tahun) atas minat berwirausaha.

\section{Kesimpulan dan Saran}

Kebebasan dalam bekerja memiliki pengaruh positif dan signifikan terhadap intensi berwirausaha. Keberhasilan diri yang lebih besar yang diperoleh mahasiswa dapat meningkatkan jiwa entrepreneur (wirausahawan) dalam diri mahasiswa. Toleransi resiko memiliki pengaruh positif dan signifikan terhadap intensi berwirausaha. Toleransi yang lebih besar terhadap risiko akan memberikan jiwa entrepreneur (wirausahawan) yang lebih besar dalam diri mahasiswa. Keberhasilan diri memiliki pengaruh positif dan signifikan terhadap intensi berwirausaha. Kebebasan yang lebih besar dalam pemilihan pekerjaan akan memberikan jiwa entrepreneur (wirausahawan) yang lebih besar dalam diri mahasiswa. Kebebasan dalam bekerja memiliki pengaruh positif dan signifikan yang dominan terhadap keinginan mahasiswa untuk menjadi seorang entrepreneur (wirausahawan).

Berkaitan dengan faktor Keberhasilan diri, aspek ketekunan dan keuletan dalam bekerja nampaknya masih menjadi hal yang paling kurang diperhatikan oleh mahasiswa. Untuk itu dalam banyak hal mengaitkan ketekunan dalam kuliah dan keuletan sebagai bagian awal dari pemupukan jiwa kewirausahaan nampaknya harus menjadi latihan awal mahasiswa. Faktor toleransi resiko, kesukaan akan tantangan yang dimiliki mahasiswa dapat memperkecil toleransi resiko yang dipupuk. Untuk itu berbagai pembelajaran diri dalam menemukan tantangan baru harus selalu dimiliki mahasiswa. Faktor kebebasan dalam bekerja, aspek 
pengambilan prakarasa atau inisiatif harus menjadi salah satu upaya untuk memperoleh peluang dan membuat peluang usaha baru. Dengan demikian hal ini mesti dilatih dalam pembelajaran di kampus.

\section{DAFTAR PUSATAKA}

Adhitama, Paulus Patria. 2014. Faktor-Faktor Yang Mempengaruhi Minat Berwirausaha (Studi Kasus Mahasiswa Fakultas Ekonomika dan Bisnis Undip, Semarang). Skripsi: tidak diterbitkan. 1-52.

Ahda Vilathuvahna, Ananda dan R D A Nugroho, Taufik. 2015. Intensi Kewirausahaan Mahasiswa Universitas Trunojoyo Madura. Agriekonomika, Vol 4, No. 1.107-119.

Angki Adi Tama. 2010. Analisis Faktor-Faktor yang Memotivasi Mahasiswa Berkeinginan Menjadi Entepreneur (Studi pada Mahasiswa S1 Fakultas Ekonomi Universitas Dipenegoro Semarang). Skripsi: diakses dari www.eprints.undip.ac.id.

Ariyani, Lilis. 2016. Faktor-Faktor Yang Mempengaruhi Intensi Berwirausaha Pada Kalangan Mahasiswa (Studi Kasus Pada Mahasiswa FEB UMS). Skripsi: tidak diterbitkan. 1-19.

Azwar, Saifuddin. 2012. Sikap Manusia. Teori dan Pengukurannya. Cetakan XVII. Pustaka Pelajar Offset. Yogyakarta.

Handaru, Agung Wahyu, dkk. 2014. Pengaruh Sikap, Norma Subjektif, dan Efikasi Diri Terhadap Intensi Berwirausaha Mahasiswa Magister Management (Kajian Empiris pada Sebuah Universitas Negeri di Jakarta). 1046-1061.

Maharini. 2013. Analisis Diskriminan Kepuasan Masyarakat Terhadap Kualitas Pelayanan Administratif Di Kantor Kecamatan Tulakan Kabupaten Pacitan. Skripsi: tidak diterbitkan.1-113.

Mahesa, Aditya Dion. 2012. Analisis Faktor-Faktor Motivasi yang Mempengaruhi Minat Berwirausaha. Diponegoro Journal of Management. 130-137.

Malo, Matesh dan Amelia. 2011. Analisis Faktor-Faktor yang Mempengaruhi Niat Kewirausahaan Mahasiswa Universitas Pelita. Jurnal Ekonomi Universitas Pelita Harapan Surabaya, 2(12), 79-84.

Pangkey, Max. 2010. Analisis Faktor-Faktor Penyebab Pengunduran Diri Karyawan Waktu Tertentu Pada Pt. Sinar Pure Foods International. Journal Article. h: 11.

Pratiwi, Yenni dan Wardana, I. 2016. Pengaruh Faktor Internal dan Eksternal Terhadap Minat Berwirausaha Mahasiswa Fakultas Ekonomi dan Bisnis Universitas Udayana. E-Jurnal Manajemen Unud, Vol.5. h. 1-28.

Raditya, K. (2016). Pengaruh Lingkungan Kerja Fisik Dan Kompensasi Finansial Terhadap Kepuasan Kerja Bagian Tukang Jahit Yara Garment. E-Jurnal Manajemen Universitas Udayana, 5(3).

Rahmadi, Afif Nur dan Heryanto Budi. 2010. Analisis Faktor-Faktor Yang Mempengaruhi Minat Berwirausaha Pada Mahasiswa Program Studi Manajemen Fakultas Ekonomi Universitas Kadiri. Skripsi: tidak diterbitkan. h: 1-17.

Santosa, Tri Djoko, Pengaruh Adversity Quotient Dan Faktor Kontekstual Terhadap Intensi Berwirausaha Berbasis Teknologi (Technopreneurship) Mahasiswa Stmik Duta Bangsa. Duta.com, Vol. 8, No.2. h: 1-7. 
Sjahruddin, Herman. 1980. Discrimnant Analysis (Analisis Diskriminan) Disajikan Pada Kuliah Metode Kuantitatif Manajemen. Bahan Kuliah Program Magister STIM Nitro. 1-71.

Suhartini, Yati. 2011. Analisis Faktor-Faktor yang Mempengaruhi Minat Mahasiswa Dalam Berwirausaha (Studi Pada Mahasiswa Universitas PGRI Yogyakarta). AKMENIKA UPY. 9(10): 1-15.

Sulistiyorini, Ika. 2013. Analisis Faktor-Faktor Yang Mempengaruhi Kepuasan Pelanggan Internet Speedy Reguler Menggunakan Analisis Diskriminan Di Semarang. Skripsi: tidak diterbitkan. hal: 1-122.

Sumarsono, Hadi. 2012. Faktor-Faktor yang Mempengaruhi Intensi Wirausaha Mahasiswa Universitas Muhammadiyah Ponogoro. Jurnal M anajemen, 11(2): 1-22.

Susanto, Adi. 2000. Kewirausahaan : Ghalia Indonesia. Jakarta.

Uswaturrasul, Yahya dan Sisilia, Kristina. 2011. Analisis Minat dan Motivasi Berwirausaha Mahasiswa (Pada Program Studi Administrasi Bisnis Telkom University, Angkatan 2011) Skripsi: tidak diterbitkan. 2(2) h: 1-11.

Wahab, Zulkifli S. 2015. Pengaruh Motivasi dan Mental Kewirausahaan Terhadap Minat Mahasiswa Manajemen Untuk Berwirausaha (Studi Pada Mahasiswa Prodi Manajemen Stiem Bongaya Makassar). Skripsi: tidak diterbitkan. 1-63. 